\title{
The Legal Reason of Sharia Principles for Object-Protection Rule Clause and its Implementation in Vehicle Insurance Contract of PT Asuransi Takaful Umum
}

\author{
Zil Aidi* \\ DOI: https://doi.org/10.22304/pjih.v5n2.a8
}

Submitted: July 16, 2018 | Accepted: August 31, 2018

\begin{abstract}
This research aims to identify and to analyze the legal reason for "Object Protection Rules" on vehicle insurance contract of PT Asuransi Takaful Umum based on the principles of Islamic law, the Sharia. The reason is to assure the contract, the Akad, of vehicle insurance of PT Asuransi Takaful Umum fulfills the sharia requirement. The requirement should cover only the objects permitted by the Sharia. Moreover, the Indonesian Sharia Economic Code (KHES) obliges every contract to fulfill all requirements related to objects and purposes of contract. The implementation of Object Protection Rules based on Sharia Principles in the vehicle insurance of PT Asuransi Takaful Umum is not effective. This is evidenced by the lack of explanation of the clause by PT Asuransi Takaful Umum to the insurance participants at the registration process. In addition, there is no control mechanism by PT Asuransi Takaful Umum to assure the use of insurance object as the contract goes. Furthermore, PT Asuransi Takaful Umum faces difficulties in tracing the history of insurance object use when the insurance participants make their claim.
\end{abstract}

Keywords: sharia-based object protection rules, sharia insurance, vehicle insurance.

\section{Alasan Hukum dari Adanya Klausula Ketentuan Objek Perlindungan dengan Prinsip Sharia Islam dan Penerapannya pada Perjanjian Asuransi Kendaraan Bermotor PT Asuransi Takaful Umum}

\begin{abstract}
Abstrak
Penelitian ini bertujuan untuk mengetahui dan menganalisis alasan hukum dari adanya klausula mengenai "Ketentuan Objek Perlindungan Dengan Prinsip Sharia Islam" pada polis asuransi kendaraan bermotor PT Asuransi Takaful Umum. Hasil penelitian memperlihatkan bahwa alasan hukum dari adanya klausula mengenai "Ketentuan Objek Perlindungan Dengan Prinsip Sharia Islam" pada polis asuransi kendaraan bermotor PT Asuransi Takaful Umum adalah guna menjadikan akad atau perjanjian pada produk asuransi kendaraan bermotor menjadi benar-benar sesuai dengan sharia Islam dengan sebisa mungkin hanya melindungi objek-objek asuransi yang secara sifat maupun pemanfaatannya sesuai dengan sharia Islam. Hal ini didasari oleh adanya pengaturan mengenai objek akad dan tujuan pokok akad sebagai syarat sahnya suatu akad dalam Kompilasi Hukum Ekonomi Sharia (KHES) yang menyatakan hanya objek yang sesuai dengan sharialah yang boleh ada dalam akad. Penerapan klausula mengenai "Ketentuan Objek Perlindungan Dengan Prinsip Sharia Islam" pada polis asuransi kendaraan bermotor PT Asuransi Takaful Umum dapat dikatakan belum efektif. Terlihat pada belum optimalnya sosialisasi kepada calon peserta asuransi mengenai keberadaan klausula tersebut pada proses awal permohonan penutupan asuransi. Hal ini
\end{abstract}

PADJADJARAN Journal of Law Volume 5 Number 2 Year 2018 [ISSN 2460-1543] [e-ISSN 2442-9325]

Faculty Member of the Faculty of Law, Universitas Diponegoro, Jalan Prof. Sudarto, Tembalang, Semarang. zil. aidi93@gmail.com, S.H., M.H. (Universitas Gadjah Mada). 
berlanjut pada saat periode perjanjian asuransi berjalan dimana tidak ada mekanisme untuk mengawasi penggunaan objek oleh peserta asuransi. Sejalan dengan itu pada saat proses pengajuan santunan klaim oleh peserta asuransi PT Asuransi Takaful Umum kesulitan untuk mengecek apakah kendaraan bermotor yang diasuransikan selama periode asuransi digunakan pada kegiatan-kegiatan yang sesuai dengan sharia Islam.

Kata kunci: asuransi kendaraan bermotor, asuransi sharia, objek perlindungan.

\section{A. Introduction}

Human being always faces risks, including ones that are related to possessions. Insurance exists as a result of human consideration to minimize impacts resulted from occurrence of risks. Risk is limited to minimize the possibility of its occurrence since the best condition is the condition without the occurrence of risk.

Legal definition of insurance can be found in Article 246 of the Indonesian Commercial Code (KUHD) as follows.

"Asuransi atau Pertanggungan adalah Perjanjian dengan mana penanggung mengikatkan diri kepada tertanggung dengan menerima premi untuk memberikan penggantian kepadanya karena kerugian, kerusakan atau kehilangan keuntungan yang diharapkan yang mungkin dideritanya akibat dari suatu kejadian tertentu".

[Insurance is an agreement by which an insurer is bound to a beneficiary thereof to provide reimbursement for the loss, damage, or injury of expected profit, which may be suffered due to a particular event.]

As mentioned earlier, the loss on property is a risk that quite often happens. Properties that are most likely susceptible to risks are vehicles. The high number of vehicle growth nowadays may contribute to the higher risk of accidents and lost.

In addition to vehicle insurance, there is also a phenomenon in the world of insurance, the rapid development of the Sharia insurance industry. Financial Services Authority of Indonesia has released the data that show an increasing of 2015 Sharia insurance asset for Rp26.5 trillion or 18.83\% higher than the previous year. Moreover, the total sharia insurance gross contribution is about Rp.10.5 Trillion (US\$768 million). ${ }^{1}$

The development of rapid Sharia insurance industry cannot be separated from the increasing tendency of Indonesian people who are predominantly Muslim. This is partly supported by the opinion of most Muslim clerics that declare conventional insurance as haram or riba, containing elements of uncertainty (gharar) and gambling or speculation (maisyir). ${ }^{2}$

The opinion concerning conventional insurance underlies the birth of PT. Syarikat Takaful Indonesia in 1994. Later, the PT. Syarikat Takaful Indonesia established PT. Asuransi Takaful Keluarga, which is committed in sharia life insurance, and PT

Ichsan Emrald Alamsyah (ed.), "Asuransi Syariah Terus Tumbuh”, http://www.republika.co.id/berita/koran/ syariah-koran/16/09/09/od864912-asuransi-syariah-terus-tumbuh, accessed on September 2016.

2 Abdul Ghofur Anshori, Asuransi Syariah di Indonesia, Yogyakarta: UII Press, 2008, p. 3. 
Asuransi Takaful Umum, which is committed in general Sharia insurance. ${ }^{3}$ Sharia insurance comes as a response to the anxiety of Indonesian Muslims that need insurance but are hesitate to use the conventional insurance.

In brief, there are a number of differences between sharia and conventional insurances. One of the significant differences is about the limitation of insurance object protection. Sharia insurance requires object or interest shall only be used for things in line with the sharia. ${ }^{4}$

PT Asuransi Takaful Umum as the oldest sharia insurance company in Indonesia also implements that insurance object protection limitation in their insurance products, including the vehicle insurance product. The implementation of the limitation can be seen by the existence of a clause in the policy entitled "the Rules of Object Protection based on the Sharia Principles". This clause essentially requires that object or interest shall only be used for things permitted by the sharia. If the beneficiary fails to fulfill the commitment, the beneficiary will lose rights to payment of compensation or claim when a risk occurs.

The clause "the Rules of Object Protection based on the Sharia Principles" can be found in Article 4 of the Takaful Vehicle Insurance Policy. It mentions that possessions and/or interests protected in Takaful policy shall not be used for activities and or transporting illicit goods, including but not limited to

(1) transactions that contain maisyir (gambling) elements;

(2) elements of immorality, such as pornography and the like;

(3) Non-halal (forbidden) commodity, such as drugs (narcotics, psychotropic and other addictive substances), pigs, dogs, alcohol and their derivatives;

(4) Gharar (fictitious) transactions;

(5) Transactions that contain elements of Zulum (maltreatment or exploitation);

(6) Transactions that contain elements of riba (usury); and

(7) Transactions that contain elements of riswah (bribery).

It is certainly interesting to study and to analyze the legal reason behind the clause. Moreover, it is also intriguing to study how the clause "The Rules of Object Protection based on the Sharia Principles" is applied in practical level.

\section{B. Insurance in Sharia Perspective}

Islam is not only a religion but it is also a way of life. Islam complements its adherents with a set of rules or basic legal norms commonly referred as the sharia. The sharia is the basic norm, which must be followed by Muslims based on faith related to interaction with Allah and fellow human beings. ${ }^{5}$ This basic norm can be found in the Quran and the Hadith.

\footnotetext{
Asuransi Takaful Keluarga, "Sekilas Kami”, https://takaful.co.id/profil-perusahaan/, accessed on June 2018.

4 Mohd Ma'sum Billah, Kontekstualisasi Takaful Dalam Asuransi, Selangor: Modern, Sweet \& Maxwell Asia, 2010. p. 61. Mohammad Daud Ali, Hukum Islam, Jakarta: Raja Grafindo Persada, 1998, p. 46.
} 
Rules of sharia are still general so it is not pratical to be used. Moreover, this unpractical rules of sharia primarily can be seen on rules that related to human interaction, or muamalah. This is the basis of fiqih, which principally serves to determine and to describe the basic legal norms contained in the Quran and the general provisions contained in the Sunnah (deeds) of the Prophet. ${ }^{6}$ One of the most significant is fiqih muamalah, which is vital in the life of Islamic society today. The fiqih muamalah is related to fellow human relationships, including in the context of the economy.

The main principle of muamalah is that everything, which is created by Allah, is halal, except the ones which are prohibited. ${ }^{7}$ Several things are prohibited according to fiqih muamalah perspective. They are, among others, riba, gharar (uncertainty), and maisyir (gambling). Conventional insurance, according to the majority of Ulama (Islamic Scholar) is considered haram since it contains gharar because both of parties in insurance contract do not know where the risk will happen. ${ }^{8}$ According to Syafii Antonio, conventional insurance contains gharar because the insurance participants only know the amount of money that they will get but they have no knowledge about the amount of premium that should pay, since only Allah know when the risk will occur. ${ }^{9}$

Furthermore, maisyir in conventional insurance is related with gharar. Maisyir can be seen from a speculation that should be taken by insurance participants. Insurance participants will get benefit from claim if a risk occurs. On the other hand, insurance participants will get nothing when there is no risk during the insurance contract and the premium that have been paid by them could not be returned by insurance company.

Riba also can be found in the conventional insurance. It could be seen by the policy of most conventional insurance companies to invest the premium that they collect from the insurance participants without concerning the sharia. Fixed deposit is one of the most dominant investment instrument for the conventional insurance companies since it is safe and has a low risk. Later on, the interest from fixed deposit investment will be the main source for the insurance company to pay the insurance claim. As we know, most of Ulama have considered usury as haram because according to sharia perspective, it is riba.

In addition to the existence of riba, gharar, and maisyir, another thing that makes conventional insurance haram is related to things that can be protected by the company. This can be found in conventional vehicle insurance. The phenomena related to conventional insurance products triggered the birth of sharia insurance. In Islamic terms, insurance is called takaful. Takaful is an Arabic terminology that rooted from the "kafala". It means collateral or an act to protect something. ${ }^{10}$ Ibid. Muhammad Syakir Sula, Asuransi Syariah Konsep dan Sistem Operasional, Jakarta: Gema Insani, 2004, p. 48. Ibid., p. 2.

Syafii Antonio, Asuransi dalam Perspektif Islam, Jakarta: STI, 1994, p. 13.

10 Engku Rabiah Adawiah (et.al.), Essential Guide to Takaful (Islamic Insurance), Kuala Lumpur: CERT, 2008, p. 3. 
Furthermore, in legal terms, takaful refers to an agreement of reimbursement by providing protection and compensation to the insurance participants who face losses. ${ }^{11}$

Islam already recognizes insurance since the period of Prophet Muhammad (PBUH). During the time of the prophet, Arab tribes practiced al-'aqilah. If there was a tribe member who got killed by a member of another tribe, the family of the victim will be paid by some amount of money as a compensation by the family of the murderer. ${ }^{12}$ Such readiness in paying compensation to the victim's family can be equalized to the premium paid in current insurance practices. The compensation paid to the victim's family is equal to the indemnity in the modern insurance practices. ${ }^{13}$ This concept grew rapidly until it reached the phase of sharia insurance in the modern era.

As stated previously, conventional insurance by most Ulama classified as a haram act because it is contained with riba, gharar, and maisyir. Therefore, the concept of tabarru' akad or contract emerges to minimize riba, gharar, and maisyir . Essentially, this akad or contract creates legal relationship not only between sharia insurance company and insurance participants but also between insurance participants themselves. The participants of insurance agree if there is a risk or disaster to one of them, then they will provide compensation to participants affected by the disaster. The compensation is derived from the premium funds they pay on a regular basis. This concept is commonly referred to as risk sharing among fellow insurance participants. It is permissible in Islam and even an obligation for Muslims to help each other.

\section{Fundamental Principles of Sharia Insurance}

Sharia insurance has several principles that underlie its practice and make the insurance fundamentally different from conventional insurance. These principles are as follows.

\section{Principle of Tawhid (Unity)}

Tawhid is an important aspect in the life of Muslims. Tawhid requires every human to be in accordance with the divine values. ${ }^{14}$ The implementation of this principle in the practice of Islamic insurance is to guarantee that sharia insurance prevent the prohibitions in the case of muamalah, including gharar, riba and maisyir.

\section{Principle of Adil (Justice)}

Islam is a religion that guides its adherents to be just. The opposite of justice is zulum or maltreatment and this is clearly prohibited by the teachings of Islam. This prohibition can be seen in Chapter Huud verse 18, which states that Allah condemns those who do wrong to others. The application of the principle of justice to sharia

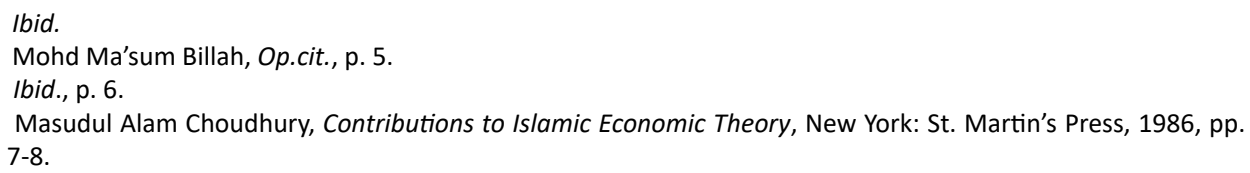


insurance lies on the obligations and rights of each party. An insurance participant is obliged to pay a sum of money as a contribution to the insurance company as the fund manager. The insurance participants will later be entitled to claim compensation funds if there is a risk. ${ }^{15}$ Likewise, the insurance company has the right to receive contribution or premium money and on the other hand is obliged to pay compensation funds in the event of a risk or accident to insurance participants.

\section{Principle of Mutual Help (Ta'awun)}

Mutual help is one of the essences of sharia insurance. The concept of tabarru' is basically an embodiment of the principle of mutual help. The insurance participants must have the intention to help and ease the burden of his fellow insurance participants who are at risk or accident. ${ }^{\mathbf{1 6}}$ This is in line with the command of Allah in the Chapter Al Maidah verse 2, which commands Muslims to help each other in kindness.

\section{Principle of Cooperation}

It has become a natural law that humans are social beings. Humans cannot live without the help of others. The application of the principle of cooperation in sharia insurance is seen in the existence of the contract between the insurance company and the insurance participant.

\section{Principle of Trusworthy (Amanah)}

Amanah or trustworthy is the main value of sharia insurance. A person who is an insurance participant is obliged to convey the correct information related to payment of contribution or premium funds, and may not manipulate the losses suffered or even hide facts related to insurance objects. This dishonest act absolutely violates the teachings of Islam, which requires that every activity of muamalah be carried out honestly. ${ }^{17}$

\section{Principle of Voluntary}

Voluntary is an absolute element in every muamalah transactions. Without this principle, the entire contract of muamalah will become invalid. The implementation of this principle can be seen in the willingness of each participant of sharia insurance to contribute or to pay premium funds that function as social funds or tabbaru'.

\section{Principle of Prohibition of Riba, Gharar, and Maisyir}

Gharar, riba, and maisyir are the basis of the prohibition of all banking, insurance, mortgage, stock exchange, leasing, venture capital, etc., which do not use sharia principles. ${ }^{18}$ Riba is technically an additional take, both in buying and selling transactions or borrowing in a false manner or contrary to the principle of muamalah. ${ }^{19}$ Riba in conventional insurance can be found in investment funds owned by insurance participants in usury financial sectors such as conventional bank deposits. Gharar, or uncertainty, in conventional insurance as discussed

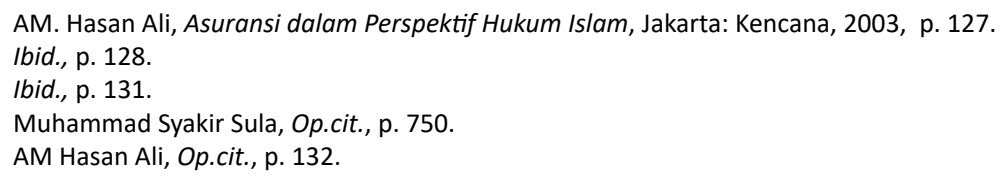


earlier occurs when insurance participants and insurance companies do not know when a risk will occur. Maisyir or commonly referred as speculation in conventional insurance, is when the insurance participant does not experience any risk then the insurance participant will not get anything, including the premium that has been paid. ${ }^{20}$

\section{H. Classification of Vehicle Insurance}

Theoretically, vehicle insurance is one of the branches of loss or general insurance. Insurance can be divided into two types as follows.

1. Commercial Insurance

Commercial insurance is an insurance that held by an insurance company as a business. The main goal is to make profit. ${ }^{21}$ The participation of participants of commercial insurance is voluntary.

2. Social Insurance

Social insurance is an insurance that is carried out not for obtaining profit, but to provide social security to the community or a group of people. ${ }^{22}$ Participation of this type of insurance is mandatory by law. The Social Insurance Administration Organization (BPJS) is an example.

Loss insurance is an insurance that covers compensation costs for damage or destruction of the insured property for purposes agreed in the insurance agreement. Loss insurance covers all objects that have economic values. ${ }^{23}$ The objects of loss insurance include buildings, vehicles, warehouse factories, and others that have economic values.

In terms of regulations, the Indonesian Commercial Code or KUHD does not regulate vehicle insurance specifically. This condition leads to the application of general regulations of loss insurance to vehicle insurance, plus the agreement of the parties in the policy. ${ }^{\mathbf{2 4}}$

The objects that can be insured in vehicle insurance $\operatorname{are}^{\mathbf{2 5}}$

1. all types of motor vehicles;

2. additional equipment contained in the motor vehicle (e.g. radio, tape, etc.);

3. responsibility according to law against third parties; and

4. various types of heavy equipments.

Essentially, sharia insurance is not to create a system that is completely different from conventional insurance. However, the purpose of sharia insurance is to minimize aspects, which are prohibited by Sharia and to avoid insurance to protect non-sharia objects. Moreover, this condition allows other aspects of conventional insurance to remain valid as long as they do not conflict with the Sharia principles.

\footnotetext{
Gemala Dewi, Aspek-Aspek Hukum Dalam Perbankan dan Asuransi Syariah, Jakarta: Kencana, 2007, p. 150.

Man Suparman Sastrawidjaja, Aspek-Aspek Hukum Asuransi dan Surat Berharga, Bandung: Alumni, 2003, p. 87. Ibid.

Mulyadi Nitisusastro, Asuransi dan Usaha Perasuransian di Indonesia, Bandung: Alfabeta, 2013, p. 134.

Abdulkadir Muhammad, Hukum Asuransi Indonesia, Bandung: Citra Aditya, 2011, p. 180.

Herman Darmawi, Manajemen Asuransi, Jakarta: Bumi Aksara, 2001, p. 133.
} 
The sharia vehicle insurance generally has the same system and regulations as conventional insurance.

\section{Contract or Akad in Sharia Insurance}

The fundamental difference between conventional and sharia insurances is on the agreement. In the conventional insurance, contract only involve the insurer or the insurance company with the insured or insurance participants. This is different from the sharia insurance; the contract does not only create a legal relationship between the insurance participants and the insurance company, but also among the insurance participants.

Sharia insurance in Indonesia has several types of contracts or akad. These akad are, among others, akad tabarru' and akad tijarah, which consist of akad wakalah bil ujrah, akad mudharabah, and akad mudharabah musytarakah. Moreover, the legal basis for the regulation of these contracts or akads is found in the fatwa of the National Sharia Council of the Indonesian Council of Ulama. It is also governed by the Regulation of the Minister of Finance number 18/PMK.010/2010 as amended by the Regulation of the Minister of Finance number 227/PMK.010/2012 on the Implementation of Basic Principles of the Operation of Insurance and Reinsurance Enterprises under Sharia Principles.

Akad tabarru' can be interpreted as a non-profit contract. This agreement can be found in the implementation of the grant on the insurance contribution by insurance participants to be allocated to tabarru' funds post to become the source of payment of claims for other insurance participants, who suffer from unfortunate or risk of objects insured in the future.

The existence of akad tabbaru' is intended to eliminate elements of gharar and maisyir. As previously discussed, the elements of gharar (uncertainty) and maisyir (speculation) exist in conventional insurance. There is no certainty when the risk will occur; there will be insurance participants who get benefit from claiming; and there will be participants who will get nothing by not making a claim. Elements that are prohibited in Sharia can be removed through the tabarru' contract because there is an element of mutual help between participants of insurance and, of course, it is allowed and even advocated by the teachings of Islam.

Akad Tijarah is a contract that aims to earn rewards for a certain profit. ${ }^{26} \mathrm{Akad}$ tijarah consists of akad wakalah bil ujrah, akad mudharabah and akad mudharabah musytarakah. Article 1 of the Regulation of the Minister of Finance number 18/ PMK.010/2010 as amended by the Regulation of the Minister of Finance number 227/PMK.010/2012 on the Implementation of Basic Principles of Operation of Insurance and Reinsurance Enterprises with Sharia Principles provide definitions on the three types of tijarah agreement. The following are the free translations of the definitions.

$26 \quad$ Abdul Ghofur Anshori, Hukum Perjanjian Islam, Yogyakarta: Gadjah Mada University Press, 2010, p. 37. 
"Akad wakalah bil ujrah is a tijarah agreement which gives power to the company as the representative of the participants to manage the tabbaru' fund and/or the investment fund of the participants in accordance with the authorized or given authority, in exchange for the form of ujrah (fee)."

"Akad mudharabah is a tijarah agreement that authorizes the company as mudharib to manage tabbaru' fund and/or investment fund of the participants in accordance with authorized or given authority, in exchange for profit sharing (nisbah) that is agreed before."

"Akad mudharabah musytarakah is a tijarah agreement that authorizes the company as mudharib to manage tabbaru' fund and/ or investment funds of the participant, combined with the company's assets, by virtue of the power or authority given, in exchange for profit sharing (nisbah) based on the combined composition of wealth that is agreed before."

Practically, a sharia insurance product will have at least two contracts or akad. The first akad is tabarru' as a voluntary contract, which creates legal relationship between the insurance participants. the second is the tijarah akad either wakalah bil ujrah, mudharabah, or mudharabah musytarakah that creates legal relationship between individual insurance participants and insurance companies.

\section{J. The Object Protection Rule Clause in Vehicle Insurance Contract of PT Asuransi Takaful Umum}

All of the Insurance products of PT Asuransi Takaful Umum including insurance of vehicle use two akad (contracts): tijarah contract, in this case wakalah bil ujrah; and tabbaru' contract. Takaful Vehicles Insurance Policy in Article 1 Point 8 defines tabbaru' contracts as a contract of grants (hibah) in the form of funds from an insured person towards tabbaru funds post, which the objective is mutual help among them and not for commercial purposes.

The definition of wakalah bil ujrah as a contract can be found in Article 1 Point 10 of Takaful Vehicle Insurance Policy. it is defined as a tijarah contract that provides authority to the manager as a deputy insurance to manage tabbaru' funds and/or other activities in connection with the management of these funds. the activities include, but are not limited to, administration activities, fund management, payment of claims, underwriting for risk portfolio management, marketing and/or investment, and as the appropriate power or authority given in return for an ujrah (fee).

A unique thing about sharia insurance, compared to conventional insurance, is the limitation on the presence of an object that can be insured. Agreement may only cover objects that do not conflict with Islamic law, either the nature or the use of the object. The obligation can be found on the Fatwa of National Sharia Board of Indonesian Ulama Council Number 21/DSN-MUI/X/2001. It is also stipulated in the Regulation of the Minister of Finance Number 18/PMK.010/2010 as amended 
by the Regulation of the Minister of Finance Number 227/PMK.010/2012 on the Implementation of Basic Principle of Insurance Business and Reinsurance Business based on Islamic Principle. The regulations essentially require that any activity undertaken by Islamic insurance company must be free of gharar (fraud), maisyir (gambling), riba, zulum (persecution), riswah, haram, and immorality. The Fatwa of National Sharia Board of Indonesian Ulama Council and the Regulation of the Minister of Finance regulate that Sharia Principles are the basis for PT Asuransi Takaful Umum to formulate clauses in the policy. ${ }^{27}$

The clause "the Rules of Object Protection based on the Sharia Principles" can be found in Article 4 of the Takaful Vehicle Insurance Policy. It mentions that possessions and/or interests protected in Takaful policy shall not be used for activities and or transporting illicit goods, including but not limited to

(1) transactions that contain maisyir (gambling) elements;

(2) elements of immorality, such as pornography and the like;

(3) Non-halal (forbidden) commodity, such as drugs (narcotics, psychotropic and other addictive substances), pigs, dogs, alcohol and their derivatives;

(4) Gharar (fictitious) transactions;

(5) Transactions that contain elements of Zulum (maltreatment or exploitation);

(6) Transactions that contain elements of riba (usury); and

(7) Transactions that contain elements of riswah (bribery).

The failure to meet these requirements will cause them to lose rights to claim. This clauses prohibit the use of insured objects, in this case is a vehicle, for activities that are prohibited by Islamic law. If the insured party does not comply with these requirements, thus their rights to claim in terms of risk will be dismissed.

The elaboration of activities prohibited in "The Rules of Object Protection based on the Sharia Principles" is as follows.

\section{Transactions that contain maisyir (gambling) elements}

The prohibition of gambling in Islamic law is contained in the Chapter Al-Maidah verse 90, which essentially commands believers to abstain from khamr or liquor, gambling, and fortune telling because these deeds are classified as haram. PT Asuransi Takaful Umum prohibits the use of objects insured on activities related to gambling transactions. The definition of gambling in this context is not only limited to activities like football bet. It also covers activities that indirectly have elements of maisyir, such as the use of insurance objects as a means of activity for non-sharia financial institutions. For instance, PT Asuransi Takaful Umum once rejected the application for insurance coverage of assets owned by nonsharia financial institutions because the activities of the conventional institution contain elements of maisyir. ${ }^{28}$

27 Interview with Denny Iriansyah Fajri as the Assistant Manager of Underwriting at PT. Asuransi Takaful Umum, November 2015.

28 Sharia Supervisory Board (DPS) of PT. Asuransi Takaful Umum opinion related to "Closure of Non Sharia Financial Institution Assets". 
The Legal Reason of Sharia Principles for Object-Protection Rule Clause and its

Implementation in Vehicle Insurance Contract of PT Asuransi Takaful Umum

\section{Containing elements of immorality such as pornography and the like}

Pornography is clearly forbidden by Islam as stated in Chapter Al-Ahzab Verse 59, which commands the Muslims to close the aurat. PT Asuransi Takaful Umum prohibits insured vehicles to be used in matters of particular acts of pornography. For example, the vehicle serves in the business of selling pornographic videos. ${ }^{29}$

3. Non-halal (forbidden) commodities such as drugs (narcotics, psychotropic and other addictive substances), pigs, dogs, alcohol, and their derivatives

Pigs and alcoholic beverages are objects that are haram according to Islam. In the context of muamalah, this is explicitly stipulated in the hadith narrated by Bukhari and Muslim, which essentially states that Allah and the Messenger forbid the sale of khamar (alcoholic beverages), carcasses, pigs, and sculptures. In addition, drugs or narcotics are also haram because Islam prohibits selfdestruction. It is regulated in the Chapter Al-Baqarah Verse 195, which forbids human to perdition. In this case, the policy of PT Asuransi Takaful Umum is very clear by prohibiting the use of insured vehicles on activities related to non-halal commodities such as pigs, dogs and narcotics. ${ }^{30}$

\section{Gharar (fictitious) transactions}

Gharar can be defined as a condition where the existence of objects in a transaction is not certain. PT Asuransi Takaful Umum rejects insurance application for objects in the form of buildings and vehicles that are leased to non-sharia financial institutions. PT Asuransi Takaful Umum does not want to engage with activities that have elements of gharar. In this case, it covers the activities of conventional institutions such as banks and conventional financing institutions that are considered as transactions containing elements of gharar. ${ }^{31}$

5. Transactions that contain elements Zulum (maltreatment or exploitation) Islam forbids the sct of Zulum . The prohibition of this act is contained in Chapter Al-Baqarah Verse 258, which states that God does not give guidance to people who do wrong. Zulum is synonymous with injustice and exploitation of others, though it can also happen to oneself. Injustice can be physical, such as torture and theft, but can also be non-physical. PT Asuransi Takaful Umum prohibits the use of insured vehicles to commit crimes in the form of mistreatment and theft against others (Handoyo 2015)..$^{32}$

6. Transactions that contain elements of riba (usury)

Transactions containing riba or usury are prohibited in Chapter Al Baqarah Verse 275, which essentially states that Allah forbids usury and justifies buying and selling. PT Asuransi Takaful Umum prohibits the use of the insured object to

29 Interview with Denny Iriansyah Fajri as the Assistant Manager of Underwriting at PT. Asuransi Takaful Umum, November 2015.

30 Interview with Joko Sri Handoyo as the head of PT. Asuransi Takaful Umum Yogyakarta Branch, September 2015.

31 Interview with Denny Iriansyah Fajri as the Assistant Manager of Underwriting at PT. Asuransi Takaful Umum, November 2015.

32 Interview with Joko Sri Handoyo, as the head of PT. Asuransi Takaful Umum Yogyakarta Branch, September 2015. 
conduct usury transactions, such as the use of vehicles for conventional bank that using usury in their operational. ${ }^{33}$

\section{Transactions that contain the elements of riswah (bribery)}

Riswah or bribery is a forbidden thing in Islam since it destroys professionalism and harms others who do not take bribes. In a hadith narrated by Abu Daud and Tirmidhi, the Messenger of Allah cursed the one who gives riswah. PT Asuransi Takaful Umum prohibits the use of insurance objects as a means to provide bribes either as a means of transportation or as an object of bribery. ${ }^{34}$

Although "The Rules of Object Protection based on the Sharia Principles" has specified the prohibited activities, other activities that are not covered by the clauses are permitted as long as the activities are not contrary to the sharia. It is accommodated in the statement on the clause that protected property and/or interest in Takaful (Sharia Insurance) is not used for the activities and/or carrying goods that are haram, including but not limited to ... That statement gives PT Asuransi Takaful Umum authority to add and to interpret activities outside "The Rules of Object Protection based on the Sharia Principles".

The aim of the provision of this clause is to create an insurance contract, in this case wakalah bil ujrah and tabbaru', that is truly in accordance with Islamic law and to eliminate elements making it null and void, notably ones concerning utilization of the insured objects that are not in accordance with sharia. ${ }^{35}$ PT Asuransi Takaful Umum does not want the wakalah bil ujrah between warrantees become null and void legally under Islamic law because the protected risk comes from elements in contrary to the nature of the Sharia. ${ }^{36}$ In line with these objectives, PT Asuransi Takaful Umum seeks to make the tabbaru' akad among warrantees to become one conformed contract of Sharia. Akad tabbaru', which the initial goal is to help each warrantee, as an insurance contract, will be invalid when the object does not comply with Islamic law. ${ }^{37}$

The clauses become important and particular especially in relation to the utilization of the insured objects. Under specified conditions, PT Asuransi Takaful Umum can refuse from the outset for insurance on an object. However, it takes some sort of instrument to control the use of the object of insurance during the period when the insurance runs. This is important because the potential of the use of vehicles is clear. PT Asuransi Takaful Umum argues that things should be in line with the conception of akad in Islam that forbids objects that are not comply with sharia not to be included in an agreement or contract. Akad or contracts shall be in harmony with the Islamic law and meet the requirements. Rukun is something that

33 Sharia Supervisory Board (DPS), Sharia Supervisory Board (DPS) view of PT Asuransi Takaful Umum related "Closing Assets of Participants Saved At Conventional Banks".

34 Interview with Joko Sri Handoyo, as the head of PT. Asuransi Takaful Umum Yogyakarta Branch, September 2015.

35 Interview with Denny Iriansyah Fajri as the Assistant Manager of Underwriting at PT. Asuransi Takaful Umum, November 2015.

36 Ibid.

37 lbid. 
should exists in the contract or called as the elements that build up the contract. Conditions are traits that should exist in every rukun, but it is not a rukun. ${ }^{38}$

The differences between rukun and conditions can be observed from a purchase agreement. The object of the sale is a pillar or forming elements of the purchase agreement. The absence of the object of buying and selling means that a purchase agreement never exist. ${ }^{39}$ Although they are different, the position of rukun and conditions are at the same level in sharia, determining the validity of a transaction..$^{40}$

Rukun akad is stipulated in Article 22 of the Compilation of Economic Sharia Act (KHES). The term akad is stipulated in Articles 23, 24, and 25 of the KHES. The arrangements of rukun and conditions on KHES requirements are as follows.

\section{The Parties do Akad}

Article 23 of the KHES determines that the parties are individuals, associations, or entities that have proficiency in legal acts.

\section{Akad's Objects}

Article 24 of the KHES states that the object of the contract can be amwal (treasures) and services that are permitted and required by each party. Object is engaged to the concept of Islam and may be goods or services. Muslim scholars agreed that the object in the engagement of Islamic law must meet the following four requirements. ${ }^{41}$

a. The object must already exist concretely when the contract is concluded or at least can be expected to exist in the future as in salam akad (reservations) and ljarah.

b. The object of the contract shall be the object justified by the sharia. Objects that are clearly forbidden in the texts, such as liquor, pork, carcass, and blood, or other forms of services such as prostitution and murder. ${ }^{42}$

c. The object must be submitted when the contract or agreement, not as to be handed over immediately but can be submitted at a specified time by the contract or agreement.

d. The object must be clear and recognizable by both sides to prevent disputes in the future.

\section{The Main Objectives of Akad}

Article 25 states that the purpose of $a k a d$ is to fulfill the needs of life and business development for each party in the contract. Basyir classifies conditions to be achieved to legitimate a contract objectives and constructing legal purposes. They are as follows. ${ }^{43}$

a. The objective of a contract is never an obligation from existed parties

\footnotetext{
Abdul Manan, Hukum Ekonomi Syariah dalam Perspektif Kewenangan Peradilan Agama, Jakarta: Kencana, 2011, p. 82.

Ibid.

Gemala Dewi (et.al.), Hukum Perikatan Islam, Jakarta: Kencana, 2005, p. 57.

Abdul Manan, Op.cit., p. 84.

Gemala Dewi, Hukum Perikatan Islam, Op.cit., p. 67.

Ahmad Azhar Basyir, Asas-Asas Hukum Muamalat, Yogyakarta: UII Press, 2000, pp. 68-71.
} 
without having akad performed.

b. Objectives should last until the execution of the contract.

c. The purpose of akad must be justified by syara'.

\section{4. ljab and Kabul.}

Ijab is a statement of promise or offer of the first party to do or not to do something. Kabul is a declaration of the acceptance of both parties on the offer made by the first party. ${ }^{44}$

Based on the arrangement of the rukun and the terms of the contract, PT Asuransi Takaful Umum includes "The Rules of Object Protection based on the Sharia Principles" as a means to make the contract on vehicle insurance be in accordance with Islamic law. One of the conditions of the contract is related to the object of the contract as provided in Article 24 of the KHES, which requires halal objects only in a contract. The objects protected by sharia insurance should be classified as things that are allowed in Islam, either in the form of objects, interest, and utilization of object or interest.

In addition to the terms of the contract related to the object, the existence of the clause "The Rules of Object Protection based on the Sharia Principles" is also associated with other contract terms explaining the purposes of the contract. Although Article 25 KHES just set a little about the basic purpose of the contract, limited in the contract aims to meet the needs of life and business development of each party; there are restrictions that the contract must also be in accordance with the Sharia. Therefore, the entire agreement, which has the purpose or effect of law that is not in line with Sharia law, is invalid. ${ }^{45}$

It can be understood that the reason of the existence of the clauses is related also to the conditions of the principal objectives of the contract. Without the restrictions given by "The Rules of Object Protection based on the Sharia Principles", there is great potential for abuse in the utilization of the insurance objects that have an impact on contract.

Sharia insurance regulates the insurance objects that is not in accordance with Islamic law to be null and void. ${ }^{46}$ This is in line with the provisions of Article 26 of the KHES that a contract is not valid when the contract is contrary to Islamic law. Article 28 point (3) also qualifies a contract that does not meet the rukun or condition is a void contract.

\section{E. The Implementation of The Object Protection Rule Clause in Vehicle Insurance Contract of PT Asuransi Takaful Umum}

The implementation of the Object Protection based on the Sharia Principles on vehicle insurance products of PT Asuransi Takaful Umum can be seen in three stages as follows.

\footnotetext{
Gemala Dewi, Op.cit., p. 9.

45 Fathurrahman Djamil, Penerapan Hukum Perjanjian dalam Transaksi di Lembaga Keuangan Syariah, Jakarta: Sinar Grafika, 2012, p. 38.

46 Interview with Prof., Dr. Muhammad., M.Ag. as sharia economic expert, December 2016.
} 
The Legal Reason of Sharia Principles for Object-Protection Rule Clause and its

Implementation in Vehicle Insurance Contract of PT Asuransi Takaful Umum

\section{At the time of the vehicle insurance registration}

The first stage is an important one because this is where the insurance company can determine the object to be insured following the use of the object. At this stage, the insurance company should provide an explanation regarding the existence of The Object Protection Rule Clause based on the Sharia Principles on motor vehicle insurance applicants. However, based on an interview with an insurance participant in Yogyakarta branch, there is no explanation of the existence of the The Object Protection Rule Clause based on the Sharia Principles in the policy or explanation regarding the prohibition of the use of objects of insurance on activities which is contradictory to Islamic law. ${ }^{47}$

\section{At the time of the insurance period runs}

At this stage, there is no control mechanism by PT Asuransi Takaful Umum to ascertain whether the insured object is used only on activities that is in accordance with Islamic law as stated in the policy. ${ }^{48}$ Another insurance participant also says that there is no question or supervision conducted by PT Asuransi Takaful Umum to ensure that the insured motor vehicle is not used on things that are contrary to Islamic law. ${ }^{49}$

\section{At the time of filing the compensation claim motor vehicle insurance}

Based on an interview, there has been no denied compensation claims for violating the provisions of Object Protection clause based on the Sharia Principles..$^{50}$ This is because there is no mechanism that allows the PT Asuransi Takaful Umum to check in detail and clearly related to the use of objects that are insured during this time and whether the object is exposed to a risk of being used for activities that are prohibited in these clauses. The process of filing compensation focus entirely on reports and chronology of insurance participants, although the object will be verified by PT Asuransi Takaful Umum but it will be difficult to check in detail whether the object is used on things that are sharia-compliant or not. ${ }^{51}$

PT Asuransi Takaful Umum stating that they are dependent on the good faith and honesty of insurance participants in applying the clause "The Rules of Object Protection based on the Sharia Principles". It is right, but of course PT Asuransi Takaful Umum still need to optimize the effort to make sure this clause can be implemented properly. ${ }^{52}$

As stated by the PT Asuransi Takaful Umum that in applying the clause "The Rules of Object Protection based on the Sharia Principles" good faith is needed from the insurance participants. The principle of good faith alone in conventional

\footnotetext{
Interview with Indriani Nur as the vehicle insurance participant at PT. Asuransi Takaful Umum, January 2016.

48 Interview with Denny Iriansyah Fajri as the Assistant Manager of Underwriting at PT. Asuransi Takaful Umum, November 2015.

49 Interview with Unteaningsih as the vehicle insurance participant at PT. Asuransi Takaful Umum, January 2016.

50 Interview with Joko Setiono as the Head of Claim at PT. Asuransi Takaful Umum, November 2015.

52 Interview with Denny Iriansyah Fajri as the Assistant Manager of Underwriting at PT. Asuransi Takaful Umum, November 2015.
}

51 lbid. 
insurance is commonly referred to as the principle of utmost good faith or can be interpreted as a perfect honesty.

Islam also recognizes the principle of good faith as a requirement of akad in Sharia Islam. Settings on the good faith can also be found in the Indonesia Sharia Economic Code (KHES). Article 21 KHES make good faith as one of the principles in the contract. In essence, the article stated that good faith is deemed to have fulfilled when a contract is done in order to uphold the welfare and does not contain elements of traps and other bad deeds. The obligation to be honest this should be done by both parties either the participants or the insurance company insurance. Insurance participants should provide all the information required by the insurance companies related to insured object. Otherwise, the insurance company must also provide information to the participants regarding the policy agreement as well as the results of management, and claims when it happened. ${ }^{53}$

Although in practice the Object Protection clause relies on the good faith and honesty of the warrantees of the insurance, this does not necessarily make the PT Asuransi Takaful Umum can only be passive without doing anything on the implementation of this clause. Instead, PT Asuransi Takaful Umum is obliged to make efforts so that this clause can be run well.

Optimization is required at every stage in the process of the insurance agreement. During the early stages, the insurance requires a Standard Operating Procedure (SOP) in disseminating information and explanations to the applicants regarding this clause. In the early stages of this insurance coverage, PT Asuransi Takaful Umum should optimize the role of the agents. The role of agents is important because the agent is the liaison between the values that will be delivered to the applicants. The next stage is when the insurance agreement runs. At this stage, it takes some kind of oversight mechanisms related to the allotment of the insurance object to be in accordance with sharia. Mechanism that can be done by the insurance company is to re-engage the agents to at least periodically ask and remind the customer about the clauses. It can also be initiated by a mechanism, which requires the insurance participants to report the use of the insurance object.

Next is the last stage that is at the time of filing the compensation claim. At this stage, the optimal verification is needed to track the use of insurance object during the insurance period. In this case, the role of the insurance claim department is important so that the verification process can be carried out more thoroughly and jellies in examining the application for compensation claim filed by insurance participant.

In the case of Islamic insurance company has optimized the efforts to ensure the objects in accordance with Islamic law, but the insurance participant violate it without the knowledge of the Islamic insurance company, the contract is not unlawful and can continue to run. ${ }^{54}$ The legal basis for these can be found in the

$53 \quad$ Muhammad Syakir Sula, Op.cit., p. 239.

54 Interview with Prof., Dr. Muhammad., M.Ag, as a sharia economic expert, December 2016. 
following hadith narrated by Bukhari and Muslim that if a judge has put all efforts to determine a law then it turns out he is right, so he gets two rewards, and if he is wrong so he gets a reward. The hadith suggests that even the judges or mujtahid still have the possibility to make mistake. However, this does not eliminate the obligation of a Muslim to keep striving for excellence in gaining knowledge because as has been stated, one must mobilize all efforts to determine a law or to gain knowledge. This hadith can be contextualized in Islamic insurance company by putting all efforts to ensure that the Object Protection clause based on the Sharia Principles is run well. Under these conditions, the contract of insurance is not null and can continue to run in the perspective of Islamic law.

\section{Conclusion}

The reason of the existence of the Object Protection clause based on the Sharia Principles in vehicle insurance policy of PT Asuransi Takaful Umum is to make the contract, the wakalah bil ujrah and tabbaru', to be completely in accordance with Sharia and to protect only sharia objects. It is based on the regulation of Indonesia Sharia Economic Code (KHES) about the object and the purpose of the contract as the conditions of contract validity.

The Implementation of the Object Protection clause based on the Sharia Principles on vehicle insurance of PT Asuransi Takaful Umum is not optimal for the following reasons.

1. At the process of insurance registration, there is a lack of explanation by PT Asuransi Takaful Umum to the insurance participants related to Object Protection clause based on the Sharia Principles.

2. At the time of the insurance period, the clause also does not run properly due to the lack of a mechanism to monitor the use of the insurance object.

3. The process of claim does not enable PT Asuransi Takaful Umum to track the compliance of participants on the Object Protection clause based on the Sharia Principles.

Although the implementation of the clause is focused on the good faith of the insurance participants, still it can be optimized both in the form of socialization and supervision. When PT Asuransi Takaful Umum already have their optimal effort to make sure the insurance object is used only for activities that comply with sharia, but the insurance participants abuse the use the object without the knowledge of PT Asuransi Takaful Umum, then the insurance contract may still continue. Violation on the clause gives rights to PT Asuransi Takaful Umum to conduct cancellation of the insurance agreement.

PT Asuransi Takaful Umum should have a Standard Operating Procedure (SOP) as a guideline for agents or other parties involved in disseminating information and better understandings of the Object Protection clause based on the Sharia Principles to prospective participant of vehicle insurance. A mechanism is also needed to perform supervision of the use of insured objects during the period of insurance. 
This can be realized by imposing the obligation periodically by insurance participants to report the use of insured objects. It also can involve an active role of the insurance agency as a liaison between PT Asuransi Takaful Umum with insurance participants. Optimization is also required in the process of checking the object when participant make claim to ensure that the insured object is utilized only on activities that are in accordance with Islamic law.

\section{References}

Books

Abdul Ghofur Anshori, Asuransi Syariah di Indonesia, UII Press, Yogyakarta, 2008.

Yogyakarta, 2010.

Abdul Manan, Hukum Ekonomi Syariah dalam Perspektif Kewenangan Peradilan Agama, Kencana, Jakarta, 2011.

Abdulkadir Muhammad, Hukum Asuransi Indonesia, Citra Aditya, Bandung, 2011.

Adawiah, Engku Rabiah (et.al.),, Essential Guide to Takaful (Islamic Insurance), CERT, Kuala Lumpur, 2008.

Ahmad Azhar Basyir, Asas-Asas Hukum Muamalat, UII Press, Yogyakarta, 2000.

AM. Hasan Ali, Asuransi dalam Perspektif Hukum Islam, Kencana, Jakarta, 2003.

Choudhury, Masudul Alam, Contributions to Islamic Economic Theory, St. Martin's Press, New York, 1986.

Fathurrahman Djamil, Penerapan Hukum Perjanjian dalam Transaksi di Lembaga Keuangan Syariah, Sinar Grafika, Jakarta, 2012.

Gemala Dewi (et.al.), Hukum Perikatan Islam, Kencana, Jakarta, 2005.

Gemala Dewi, Aspek-Aspek Hukum Dalam Perbankan dan Asuransi Syariah, Kencana, Jakarta, 2007.

Herman Darmawi, Manajemen Asuransi, Bumi Aksara, Jakarta, 2001.

Man Suparman Sastrawidjaja, Aspek-Aspek Hukum Asuransi dan Surat Berharga, Alumni, Bandung, 2003.

Mohammad Daud Ali, Hukum Islam, Raja Grafindo Persada, Jakarta, 1998.

Mohd Ma'sum Billah, Kontekstualisasi Takaful Dalam Asuransi, Modern, Sweet \& Maxwell Asia, Selangor, 2010.

Muhammad Syakir Sula, Asuransi Syariah Konsep dan Sistem Operasional, Gema Insani, Jakarta, 2004.

Mulyadi Nitisusastro, Asuransi dan Usaha Perasuransian di Indonesia, Alfabeta, Bandung, 2013.

Syafii Antonio, Asuransi dalam Perspektif Islam, STI, , Jakarta, 1994.

\section{Other Documents}

Asuransi Takaful Keluarga, "Sekilas Kami", https://takaful.co.id/profil-perusahaan/, accessed on June 2018. 
The Legal Reason of Sharia Principles for Object-Protection Rule Clause and its

Ichsan Emrald Alamsyah (ed.), "Asuransi Syariah Terus Tumbuh", http://www. republika.co.id/berita/koran/syariah-koran/16/09/09/od864912-asuransisyariah-terus-tumbuh, accessed on September 2016.

\section{Legal Documents}

Indonesian Commercial Code.

The Regulation of Indonesia Supreme Court Number 2/2008 on the Indonesia Sharia Economic Code (KHES).

The Regulation of Minister of Finance Number 18/PMK.010/2010 as amended by the Finance Minister Regulation Number 227/PMK.010/2012 on the Implementation of Basic Principle of Insurance Business and Reinsurance Business Using Islamic Principle.

Fatwa of National Sharia Board of Indonesian Ulama Council No. 21/DSN-MUI/X/2001 on General Guideline of Sharia Insurance.

Policy of Takaful Vehicle Insurance of PT Asuransi Takaful Umum. 